\title{
Treatment Plant Instructional Modules in Environmental Engineering
}

\author{
Joseph R.V. Flora and A. Steve McAnally \\ University of South Carolina
}

\begin{abstract}
The Environmental Engineering Curriculum Innovation and Development (CID) group within the National Science Foundation (NSF) Gateway Coalition systematically developed and evaluated instructional modules in various fields of environmental engineering. This paper describes the activities conducted by professors at the University of South Carolina (USC) as part of the group. Six treatment plant instructional modules based on SuperPro Designer ${ }^{\circledR}$ were developed at USC: one software instructional module and five instructional modules based on individual and multiple combinations of unit operations. These modules underwent two rounds of beta testing at USC and were sent to professors at The Cooper Union (CU), Polytechnic University (PU), and Case Western Reserve University (CWRU) for evaluation. In turn, USC professors evaluated modules developed at CU and PU. The development of evaluation procedures for the instructional modules was performed in conjunction with a professional external evaluator. The evaluation had two basic components: an instructor review and an evaluation by the students. The instructor review involved a technical review of module documentation as well as an evaluation of the effectiveness and practicality of implementing the module. The students evaluated the quality and usefulness of the software application and the instructor's approach in implementing the instructional modules. The modules were revised based on the beta test results.
\end{abstract}

\section{Introduction}

In the summer of 1995, educators from seven institutions within the NSF Gateway Coalition formed the Environmental Engineering CID and initiated the development of a series of prototype case study, database, and environmental software modules to support environmental engineering education. These modules were packaged as educational resources that can easily be distributed and incorporated into the environmental curricula of institutions within and beyond the Coalition. During the 1995-1996 academic year (year 4 of the NSF Gateway Coalition project), shared resources modules were produced in four focus areas: solid and hazardous waste, water/wastewater treatment and environmental chemistry, air pollution, and environmental hydraulics and water resources. Beta tests of these modules were systematically conducted during the 1996-1997 academic year (year 5 of the project) where modules were exchanged between universities based on expertise demonstrated during the module development activities at each beta test site.

Professors at USC focused on developing and testing instructional modules based on SuperPro Designer $^{\circledR}$. SuperPro Designer ${ }^{\circledR}$ is a commercial software package that can be used to design water and wastewater treatment, air pollution control, and industrial unit operations ${ }^{1}$. Different 
combinations of unit operations can be simulated and complete treatment plants can be designed $^{2}$. Based on the ideal characteristics of software for engineering education applications proposed by Jennings ${ }^{3-5}$, SuperPro Designer ${ }^{\circledR}$ has excellent potential to be used as part of instruction in environmental engineering. Six instructional modules were produced and evaluated on-site, as well as evaluated by professors and students at CU, PU, and CWRU. The following sections describe the modules developed and the evaluation activities.

\section{Description of the Instructional Modules}

Based on the prototype module developed in the summer of 1995, six modules were developed during year 4: one software instructional module and five instructional modules based on individual and multiple combinations of unit operations (see Table 1 for module titles and development timeline). The philosophy behind the development of the software module was to provide instructors in the field of water and wastewater treatment a means of assessing SuperPro Designer $^{\circledR}$ for potential use in instruction. The module was intended to complement the user's manual provided with the software package. The tutorial section in the user's manual was general and showed many facets of the software. However, the tutorial may not contain sufficient detail for individuals to immediately use and evaluate the software. The module was developed to provide detailed procedures to accelerate the use of the software.

The philosophy behind developing the unit operations modules was to provide instructors with a reference for classroom instruction. Detailed solution procedures for the design of specific unit operations were provided and could be distributed to the students to enhance their learning and supplement classroom instruction. Documentation on illustrative problems was provided, and the solutions to all the problems in the module are contained in an accompanying diskette.

\section{In-House Evaluation of the Instructional Modules Developed at USC}

Evaluation procedures for the instructional modules were developed in conjunction with a local evaluator. The evaluation had two basic components: an instructor review and an evaluation by the students. The instructor review involved a technical review of module documentation as well as an evaluation of the effectiveness and practicality of implementing the modules. The students evaluated the quality and usefulness of the software application and the instructor's approach in implementing the instructional modules. To ensure an independent in-house technical evaluation of the modules, one faculty member had the primary responsibility of developing the instructional modules, while another faculty member was charged with the evaluation and implementation of these modules in class. The faculty member responsible for the evaluation had not used any of the instructional modules prior to the review process.

The instructional modules were tested by two groups of students. Four modules were implemented during the 1996 Spring Semester of a junior/senior level Environmental Engineering course entitled "Elements of Water and Wastewater Treatment." Three of the modules were implemented in the same course the following year during the 1997 Spring Semester. The objectives of this course included the development of the students' understanding of the engineering principles governing the design of physical, chemical, and biological water 
and wastewater treatment unit operations, and the integration of the students understanding into the design of municipal treatment systems.

Table 1. Instructional modules and a brief description of the timeline involved in the development and revision of the modules.

\begin{tabular}{|c|c|}
\hline Module Title & Development Timeline \\
\hline $\begin{array}{l}\text { Software } \\
\text { Instructional } \\
\text { Module }\end{array}$ & $\begin{array}{l}\text { First version completed in 08/95. Second version completed in 03/96 after } \\
\text { in-house beta-test. Third version completed in } 07 / 96 \text { after in-house beta } \\
\text { test and receipt of new software release. Fourth version completed in } \\
09 / 97 \text { incorporating external beta-test comments and the latest software } \\
\text { release. }\end{array}$ \\
\hline $\begin{array}{l}\text { Clarifier/Thickener } \\
\text { Instructional } \\
\text { Module }\end{array}$ & $\begin{array}{l}\text { First version completed in 02/96. Second version completed in } 07 / 96 \text { after } \\
\text { in-house beta test and receipt of new software release. Third version } \\
\text { completed in 09/97 incorporating external beta-test comments and the } \\
\text { latest software release. }\end{array}$ \\
\hline $\begin{array}{l}\text { Granular Media } \\
\text { Filter Instructional } \\
\text { Module }\end{array}$ & $\begin{array}{l}\text { First version completed in 04/96. Second version completed in 08/96 after } \\
\text { receipt of new software release. Third version completed in 09/97 } \\
\text { incorporating external beta-test comments and the latest software release. }\end{array}$ \\
\hline $\begin{array}{l}\text { Aerobic Treatment } \\
\text { Instructional } \\
\text { Module }\end{array}$ & $\begin{array}{l}\text { First version completed in 04/96. Second version completed in 08/96 after } \\
\text { in-house beta test and receipt of new software release. Third version } \\
\text { completed in 09/97 incorporating external beta-test comments and the } \\
\text { latest software release. }\end{array}$ \\
\hline $\begin{array}{l}\text { Sludge Treatment } \\
\text { Instructional } \\
\text { Module }\end{array}$ & $\begin{array}{l}\text { First version completed in 04/96. Second version completed in 08/96 after } \\
\text { in-house beta test and receipt of new software release. Third version } \\
\text { completed in 09/97 incorporating external beta-test comments and the } \\
\text { latest software release }\end{array}$ \\
\hline $\begin{array}{l}\text { Wastewater } \\
\text { Treatment Plant } \\
\text { Design/Analysis } \\
\text { Instructional } \\
\text { Module }\end{array}$ & $\begin{array}{l}\text { First version completed in 08/96. Second version completed in 09/97 } \\
\text { incorporating the latest software release }\end{array}$ \\
\hline
\end{tabular}

Instructor Evaluation. Each instructional module was adapted in course topics that were covered in a total of 3 to 6 hour lecture periods. The instructor evaluated the practicality and effectiveness of the instructional modules by answering the questions summarized in Table 2 as each module was implemented in classroom instruction. A summary of the responses is also provided in Table 2. 
Table 2. Key instructor evaluation questions and summary of responses.

\begin{tabular}{|c|c|}
\hline Instructor Evaluation Question & Results of the Evaluation \\
\hline $\begin{array}{l}\text { 1. What is the degree of } \\
\text { compatibility of the } \\
\text { instructional module with } \\
\text { the course objectives? }\end{array}$ & $\begin{array}{l}\text { Each module was very compatible with the ECIV } 551 \text { course } \\
\text { objectives. }\end{array}$ \\
\hline $\begin{array}{l}\text { 2. What degree of effort was } \\
\text { required to evaluate the } \\
\text { module during the initial } \\
\text { "screening" review? }\end{array}$ & $\begin{array}{l}\text { The degree of effort was measured by the time required to read } \\
\text { instructions and perform example problem simulations. } \\
\text { Computer Software Module }-2.25 \text { hours* } \\
\text { Clarifier/Thickener Module }-30 \text { minutes } \\
\text { Aerobic Treatment Module }-45 \text { minutes } \\
\text { Sludge Treatment Module }-45 \text { minutes }\end{array}$ \\
\hline $\begin{array}{l}\text { 3. How does the instructional } \\
\text { module format compare to } \\
\text { the SuperPro Designer }{ }^{\circledR} \\
\text { User's Guide format for } \\
\text { utility of use in this course? }\end{array}$ & $\begin{array}{l}\text { In each case, the module format was more thorough, clear, and } \\
\text { concise in presenting each treatment operation. Furthermore, } \\
\text { the variety of problems provided along with the example } \\
\text { problem made the module a more versatile tool for the } \\
\text { instructor. The instructor was able to easily identify and } \\
\text { discuss the limitations of the software and the special solution } \\
\text { procedures required of the students. }\end{array}$ \\
\hline $\begin{array}{l}\text { 4. What degree of effort was } \\
\text { required to implement each } \\
\text { instructional module in the } \\
\text { classroom instruction? }\end{array}$ & $\begin{array}{l}\text { The Clarifier/Thickener Module could be easily implemented } \\
\text { within a 3-hour class period. Due to time limitations, the } \\
\text { instructor implemented the Aerobic Treatment and Sludge } \\
\text { Treatment Modules within a 4-hour class period. The concepts } \\
\text { and principles for biological treatment are more complicated. } \\
\text { Given the students' background, more time needed to be spent } \\
\text { discussing fundamental concepts (e.g., stoichiometry of } \\
\text { biological reactions). This would have led to a more detailed } \\
\text { explanation of the input parameters to the design procedures. } \\
\text { These modules were viewed as more cumbersome by some of } \\
\text { the students because the input required stepping through } \\
\text { numerous sub-windows. }\end{array}$ \\
\hline
\end{tabular}

* The Computer Software Module took more time because it was the instructor's initial introduction to the software program. The instructor followed the instructions to install the program and complete the introductory example problem. Nevertheless, the screening time was relatively brief, which is very desirable given the typical demands on the instructor that limit time available for course development.

Student Evaluation. The ECIV 551 students completed two surveys at the end of the 1996 and 1997 Spring Semesters. The first survey asked the students to evaluate the instructional modules for use in classroom instruction. The second survey requested the students to evaluate the instructor and the course. The student responses are summarized in Table 3. 
Table 3. Summary of student responses regarding the modules, software, instructor, and the course.

\begin{tabular}{|c|c|}
\hline Positive Responses & Negative Responses \\
\hline $\begin{array}{l}\text { Very helpful by assisting the students in } \\
\text { visualizing the practical aspects of the } \\
\text { course. } \\
\text { - A majority of the students felt the modules } \\
\text { did reinforce learning fundamental } \\
\text { concepts (to a varying degree). } \\
\text { - Overall the students felt that the instructor } \\
\text { was effective and had a very good quality } \\
\text { of instruction } \\
\text { A couple of students majoring in } \\
\text { Structures indicated that the use of the } \\
\text { instructional modules significantly } \\
\text { increased their interest in the } \\
\text { environmental engineering course. }\end{array}$ & $\begin{array}{l}\text { - Many students felt the more involved } \\
\text { modules (Aerobic Treatment and Sludge } \\
\text { Treatment) could be stronger tools if the } \\
\text { instructor spent more time explaining the } \\
\text { input parameters. } \\
\text { - Many students felt the modules needed } \\
\text { additional unit operations. } \\
\text { - Frequent fatal errors (premature } \\
\text { termination of program) could be a } \\
\text { frustrating experience. } \\
\text { - A few students felt that the multiple sub- } \\
\text { windows during program initialization } \\
\text { could be confusing. }\end{array}$ \\
\hline
\end{tabular}

The overall conclusions from the evaluations by the instructor and the students were that the instructional modules enhanced the presentation of the course material, and it improved the students' ability to learn the course content. The overall opinion was that the modules should be used in future courses. The modules provided clear and precise procedures for solving example design problems. They were simple to implement and use, very reliable with adequate graphical output. The primary limitation to the module use was the frequency of fatal errors that prematurely terminated the program.

\section{Evaluation of Modules Developed at Polytechnic University and The Cooper Union}

In January 1997, course modules were received from PU and CU. The modules from PU were "Small Municipal Wastewater Treatment Plant Design," "Municipal + Industrial Wastewater Treatment," and "Large Wastewater Treatment Plant Design," each of which is based on the use of SuperPro Designer ${ }^{\circledR}$ v. 1.0. The CU module was entitled "Data Base Information for Municipal Wastewater, Chemical and Pharmaceutical Industries Wastewater, and Electronic Industries Wastewater." These case studies were introduced to the students of ECIV 551 as a final project for the 1997 Spring Semester. Evaluations were performed by the instructor and the students of ECIV 551. Additionally, feedback on the CU module was obtained from students in a graduate level course on the principles of biological process design.

The overall conclusions from the evaluations by the instructor and the students were that the case study modules significantly enhanced the presentation of the course material and strengthened the students' understanding of the subject matter. These modules were excellent supplemental 
tools that provided realistic information for use by the instructor in presenting case study problems.

The Polytechnic University modules provided detailed procedures for implementing illustrative design problems that required the students to apply the SuperPro Designer ${ }^{\circledR}$ software. The modules can be strengthened for a science/design type course, such as ECIV 551, by providing a more detailed example problem scenario for the instructor. Such an inclusion will allow a potential user (the instructor) to readily assess the utility of the module for a course, and easily implement the module with minimal preparation time.

The CU module provided an excellent database for practical application of case study problems in ECIV 551. The primary disadvantage identified at the time of module implementation in the course was that the instructor had to generate a case study scenario for application of the database. Since that time, the CU module has been updated to include an excellent series of case study scenarios with a detailed solution to one of the scenarios.

\section{Revision of USC Modules Based on Beta-Tests}

In addition to the in-house evaluation, the modules developed at USC were beta-tested by three external institutions: CU, PU, and CWRU. The first major revision of the modules was performed in the summer of 1996 after the internal review at USC (see Table 1). The review resulted in the addition of more detail in the procedures section of the modules, the inclusion of sections of screen printouts to facilitate coordination between the module document and the computer, the correction of several technical errors in the modules, and updating the modules to the latest working version of SuperPro Designer ${ }^{\circledR}$ (version 2.0).

The second major revision of the modules was performed in the summer of 1997. Feedback was received from CU and PU, as well as from a second round of internal reviews at USC. The reviews were very good, and did not require substantial revisions to the modules. The reviewer from CWRU suggested that interesting problems (such as performing a sensitivity analysis on some variables or evaluating the influence of clarifier shapes on removal efficiency and energy requirements) beyond the traditional textbook problems would have improved on the quality of the modules. Time constraints prevented the incorporation of this suggestion in the final set of modules submitted to the project sponsors. Hence, the revisions primarily focused on updating the modules to the latest working version of SuperPro Designer ${ }^{\circledR}$ (version 2.7).

\section{Conclusions}

The modules developed at USC, PU, and CU were distributed and incorporated into the environmental curricula of institutions beyond the module developer's home institution. Similar to textbooks, the modules developed were not universal. The use of the modules was dictated by the teaching style of the instructor, the course requirements, and the program of study in the individual institutions. Revision of the modules is a continuous and necessary process. The modules need to be updated to the current state of the art software and modified to adapt to the needs of a changing engineering curriculum. 


\section{Acknowledgements}

This effort was supported in part by the National Science Foundation Gateway Coalition grant NSF\# CID-U-05-CW. Any opinions, findings, and conclusions or recommendations expressed in this material are those of the authors and do not necessarily reflect the views of the funding agency. Mention of any specific trade name does not constitute endorsement of the product by the sponsors.

\section{References}

1. User's Guide for the Pro-Designer (BioPro, EnviroPro, and SuperPro) Family of Simulation and Design Tools for the Process and Environmental Industries, Intelligen Inc. New Jersey, 1996.

2. Petrides, D., Calandranis, J., and Flora, J.R.V. Clean Water Begins with a Mouse: A comprehensive computer simulation can simplify the task of designing a cost-effective wastewater treatment plant. Industrial Wastewater, 33-40, May/June 1997.

3. Jennings, A.A. A bioremediation teaching module based on BIO1D, Environmental Modelling and Software, 1, $1-17,1997$.

4. Jennings, A.A. and Kuhlman, S.J. An Air Pollution Transport Teaching Module Based on GAUSSIAN MODELS 1.1, Environmental Modelling and Software, in press.

5. Jennings, AA. Introduction to Educational Use of Environmental Engineering Software. Proceedings of the 1998 ASEE Annual Conference and Exposition, Seattle, WA, June 28-July 1, 1998, in press.

\section{Biographical Information}

\section{JOSEPH FLORA}

Joseph Flora is an Assistant Professor in the Department of Civil and Environmental Engineering at the University of South Carolina - Columbia. He received a B.S. in Civil Engineering from the University of the Philippines, a M.S. in Environmental Engineering from the University of Illinois at Urbana-Champaign and a Ph.D. in Environmental Engineering from the University of Cincinnati in 1993. His research interests are in the areas of environmental process modeling, electrochemically-mediated biological degradation, and water, wastewater, and hazardous waste treatment.

\section{STEVE McANALLY}

Steve McAnally is an Associate Professor in the Department of Civil and Environmental Engineering at the University of South Carolina - Columbia. He received a B.S. in Engineering at the United States Military Academy at West Point, and a M.S. and Ph.D. in Civil Engineering from Auburn University. His research interests are in the areas of water and wastewater treatment, constructed wetland treatment systems, corrosion control, pollution prevention, and environmental engineering education. He is a licensed professional engineer in the State of South Carolina. 